\begin{tabular}{|c|c|c|c|}
\hline Article Info & RESEARCH ARTICLE & ARAŞTIRMA MAKALESİ & \\
\hline Title of Article & \multicolumn{2}{|c|}{$\begin{array}{l}\text { Emancipating Urban Interventions: } \\
\text { Parasitic Spaces }\end{array}$} & Pra \\
\hline $\begin{array}{l}\text { Corresponding } \\
\text { Author }\end{array}$ & \multicolumn{2}{|c|}{$\begin{array}{l}\text { Asiye AKGÜN GÜLTEKİN } \\
\text { İKÜ, Mimarlık Fakültesi, Mimarlık Bölümü, a.akgun@iku.edu.tr }\end{array}$} & 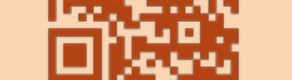 \\
\hline $\begin{array}{l}\text { Submission Date } \\
\text { Admission Date }\end{array}$ & \multicolumn{2}{|l|}{ 05.11.2019 / 08.12.2019 } & $K=N 2$ \\
\hline Author / Authors & $\begin{array}{l}\text { Asiye AKGÜN GÜLTEKIN } \\
\text { Emel BİRER }\end{array}$ & $\begin{array}{l}\text { ORCI D: } 0000-0002-3453-4559 \\
\text { ORCI D: } 0000-0003-0152-3690\end{array}$ & AKADEMİSi் \\
\hline How to Cite & \multicolumn{2}{|c|}{$\begin{array}{l}\text { AKGÜN GÜLTEKİN, A. ve BİRER, E. (2019). Emancipating Urban Interventions/ } \\
\text { Kamusal Alanda Özgürleştirici Müdahaleler: Parazit Mekanlar, Kent Akademisi, } \\
\text { Volume, } 12 \text { (40), Issue 4, Pages 729-738. }\end{array}$} & How to Cite \\
\hline
\end{tabular}

\title{
Kamusal Alanda Özgürleştirici Müdahaleler: Parazit Mekânlar
}

\section{ABSTRACT:}

It is observed that cities are transformed into consumption-oriented presentation objects. Apart from the discourse of vanishing public space different practices which is aim to create new publicities have been developed by architects and urbanists. With acceptence of the space as a social product, to create the structural action space which is penetrated to a daily routine in order to social sustainability makes people free in public space. Being visible is added to the action-based approaches, and it reflects to architectural space as parasitic structures. With its articulated structure, it spatialized, dynamizes the place we look at every day but not see, and transform the spectator into an emancipated active agent. As a stage of the gazing action, the place transformed into agency space. And this urban space practice herald to get back to city. In this study, articulation of the agency space to urban space which is transformed into consumption and theatrical thing, it is presented as a method that will make the people interact with others. It is aimed to discuss the situation arising from the products of the experimental studio which aims to design the parasite structure on the E5 journey route, which constitutes the backbone of Istanbul. The studio's products emerge as a challenge to the normalization of existing static and defined space. The concept of agency-visibilityspectator will be re-examined through the architectural designs.

Keywords: new public space, emancipation, visibility, agency, parasitic structure

ÖZ:

Günümüzde kent, tüketim odaklı bir sunum nesnesi haline dönüşmektedir. Kamusal alanın ortadan kalktığı söylemleri eşliğinde, mimarlar ve şehirciler tarafından yeni tür kamusallıkların yaratılmasına yönelik farklı pratiklerin geliştirildiği gözlemlenir. Bu pratiklerden bir tanesi, mekânı sosyal bir ürün olarak kabul eden eylemlilik halinin yaratılması ve beraberinde toplumsal sürekliliğinin sağlanmasına yönelik gündelik hayata nüfus edecek strüktürel eylem alanlarının tasarlanması ve beraberinde kamusal alanda bireyin özgürleştirilmesidir. Temelde yer alan eylemlilik anlayışına görünür olmak eklenir ve mimari mekân bu durumda karşılığını parazit strüktürlerle bulur. Mevcuda eklemlenen yapısı ile parazit, kentlinin her gün baktığı ama göremediği alanları mekânsallaştırır, dinamikleştirir ve kentliyi değişime dâhil eder. Aynı eylem, -bakmak- için de eylemsel alana dönüşür. Deneyim alanının yaşandığı kentsel mekân kenti geri almanın muştusudur. Bu çalışmanın amacı, tüketim ve seyirlik bir nesneye

${ }^{1}$ IKÜ, Mimarlık Fakültesi, Mimarlık Bölümü, a.akgun@iku.edu.tr

${ }^{2}$ İUÜ, Mimarlık Fakültesi, Mimarlık Bölümü, e.birer@iku.edu.tr 
dönüşen kente kamusal yarara dönük eylem-mekânları yerleştirerek -plug into- yeni kamusal mekân kavramını irdelemek, anlık, geçici kamusal alan müdahalelerini parazit mimari mekânlar üzerinden tartı̧̧maktır. Yapılı çevrenin özelleştirilen-ticarileşen kamusal alanlarında parazit strüktürler ile yapılı çevreye müdahale edilerek kamu yararına dönüştürmek niyeti deneysel bir stüdyonun ürünleri ile tartışmaya açılmıştır. Bu ürünler, İstanbul'un gündelik hayatında belkemiğini oluşturan E5 yolculuk güzergâhında bulunan metrobüs duraklarına yapılacak parazit müdahaleler olup, bir çeşit mekânın normalleşmesine meydan okuma olarak ortaya çıkmaktadır. Mimari ürünler ile ortaya çıkan problem alanında eylemlilik-görünürlük-izleyici kavramları yeniden ele alınır.

Anahtar Kelimeler: yeni kamusal alanlar, özgürleşme, görünürlük, eylemlilik, parazit strüktür

\section{GíRiş:}

Kamusal alanlar; nötr olmayan, kimlik ve kültürlerin ifade alanı olarak toplumsal yaşantının geçtiği dinamik platformlar olup farklı ölçeklerde etkileşimi içeren karmaşı yapıya sahip bir çevre içinde yaşayan aktörleri ile anlam kazanmaktadırlar. Diğer yandan, kamusal alanların insanı özne konumundan uzaklaştırması ve seyirci konumuna düşürmesi, kentleşme tarihi boyunca üzerine düşünülen bir problemdir. Arendth'in kamusal alan özellikleri olarak iki başlıkta ele aldığı görünürlük ve eylemlilik bağlamında özgürleştirici vaadi olan bu ortamların, üzerine spekülasyonların yapıldı ̆̆ı problem çerçevesinde yeniden okunmaya ve yorumlanmaya ihtiyacı bulunmaktadır. Kamusal mekânın stratejik ve taktiksel manipülasyonları ile bir taraftan tanımlı, okunabilir kamusal alanlar oluşturulmaya çalışılırken, diğer taraftan karmaşık, anlık deneyimlere olanak sağlayan mekânsal pratikler yaratılmaktadır. Bu çalışmada ikinci türden taktiksel mekân üretimlerinin kamusal mekânda bireyleri özgürleştirici potansiyelleri üzerinde durulmaktadır. Bu çerçevede kamusal mekân ve yeni kamusal mekân kavramları irdelenerek, anlık, geçici kamusal alan müdahaleleri parazit mimari mekânlar/strüktürler üzerinden tartışılmıştır. Kamusal alanın geri alınmasına yönelik olarak üretilen, eylemlilik ve görünürlük kavramları üzerinden mekânın manipülasyonlarına teşvik edici mimari tasarım stüdyo ürünleri bu çalışma kapsamında değerlendirilmiştir.

\section{Yeni Kamusal Alanların Vadettikleri Üzerine}

Kentsel kamusal alan ile kentlilik arasındaki ilişkinin önemine dayalı literatürde (Klasik Yunan filozoflarından, Benjamin, Simmel, Mumford, Lefebvre, Jacobs, Sennett ve Zukin gibi kent teorisyenleri ve eleștirmenlerine kadar) kamusalın birey üzerindeki pozitif etkilerine yer verilir. Yalnızlaşma ve kendine yabancılaşma, küresel kentlerin kamusal alanın etkileşime ve katılıma dayalı özelliklerinin ortadan kalkmasıyla karşı karşıya kalınan en büyük problemlerdir. Günümüz küresel kentleri, iletişim teknolojilerindeki gelişmeler, kamusal alanın ticarileşmesi ve tüketim olgularıyla kentin kamusal alanlarını dönüştürmüştür. Bu dönüşümü 1990'larda Augé, "yer olmayan-yok yerler" (non-lieux) olarak tanımlar; ĕger "yer", kimlikleyici, ilişkisel ve tarihsel olarak tanımlanabiliyorsa, kimlikleyici, ilişkisel ve tarihsel olarak tanımlanamayan da "yer olmayan"dır (Augé, 2017). Kentte, hareketleri pasifize edilmiş bireyin en çok içinde yer aldığı bu alanlar; havaalanı, otogar, alışveriş merkezleri, otobanlar olarak karşımıza çıkar. Yerle kurulan ilişki yön tabelaları, uyarıcı görsel ve yazıları ile sağlanır. Hafızası olmayan bu yerlerde görsel ilişki; kişiler arasında değil, ticarileşen kamusal alanın en önemli göstergeleri olarak reklam panoları ile gerçekleşir. Bir yandan da politik mesajlara maruz kalınan bu yerlerin pasif bir izleyicisi- "seyirci" konumunda brrakılır kentli. Ranciere (2010,s.10)'e göre, "seyirci olmak, hem bilmek kabiliyetinden hem de eylemek kudretinden kopmak demektir". Debord, seyreden insanın hastalığını seyre daldıkça daha az var olur şeklinde tarif eder (Ranciere, 2010, s.13). Seyirci konumundan kurtulmak özgürleştiricidir diye ekler; “...Bakma ile eylemde bulunma arasındaki karşıtlı̆̆ sorguladı̆̆ımız zaman; yani söyleme, bakma ve yapma arasındaki iliş̧kileri kuran olguların tahakküm ve boyun eğdirme yapısına ait olduğınu anladı̆̆ımız zaman başlar özgürleşme.” (Ranciere, 2010, s.18). Özgürleştirici bir tavır olarak eylem-icra hiç kimsenin anlamı üzerinde tekel kuramayacağı bir şeydir. Kamusal alanın politik yönünü ön plana çıkaran siyaset bilimci Arendt'e göre kamusal alan, özgürlüğün kendisini gösterebildiği yerdir (d'Entreves, 2019). Özgürlüğün ise diğerleri ile etkileşimi ve eylem gerektirdiğini ileri süren Arendt'in görüşü, Ranciere ve Debord'u benzer yönde önceleyen bir yorumdur. Kentin tiyatro sahnesi olduğu yönündeki çok bilindik bir kent metaforu kavramı üzerinden değerlendirme yapılırsa; kamusal alanı etkileşimli bir tiyatro sahnesine dönüştürme girişimleri, kent hakkını gündelik bir rutin içerisinde kısa süreliğine ele geçirmek, özgürleştirici olacaktır. Bugün var olan “yeni yer”ler, Augé'nin “yok yer”lerinin yeni kamusallıklarına olanak sağlar görünmektedir. Bu olanakların neler olduğu konusu, metnin içinde dünyadan parazit müdahalelerin örneklendiği bölümde ele alınmaktadır. 
Lefebvre(2015) "kent hakkı" kitabında gündelik hayatın içinde evden işe işten eve koşturan insanların kurgulanmış düzeni içerisindeki durumlarını düşünmeye ihtiyaçları olduklarından bahseder (s.113). Toplumsal ihtiyaçların antropolojik dayanakları olduğunu ifade eden Lefebvre bunları şu şekilde sıralar; "güvenlik ve serbestlik ihtiyacl, kesinlik ve macera ihtiyacl, çalı̧̧manın ve oyunun örgütlenmesi ihtiyacl, öngörülebilirlik ve öngörülemezlik, birlik ve farklılık, inziva ve karşılaşma, mübadele ve yatırım, bağımsızlık ve iletiş̧im, aciliyet ve uzun vadeli perspektif ihtiyact. ..insanın görmeye, işitmeye, dokunmaya, tatmaya ihtiyacı vardır ve bu algıları bir "dünya"da bir araya getirmeye ihtiyaç duyar. Bunun yanında özelleşmiş ihtiyaçları vardır. Şehir ve kentler bu ihtiyaçları karşılamaz. Özgül kentsel ihtiyaçlar, nitelikli yerlere, eşzamanlıllk ve karşılaş̧ma yerlerine, mübadelenin mübadele değerinden, ticaret ve kardan uzak kalabildiği yerlere duyulan ihtiyaçlardır".(Lefebvre, 2015,s.119-120) Rastlantısallığa yer olmayan yok yerlerde eylem tanımlıdır, işaretlerle gösterilir, her şey planlanan kurguya hizmet eder. Kamusallı̆̆ ortadan kaldıran bu kamusal alanlarda bir ihlal anı bireyi özgürleştirecek olan eylemliliği ortaya çıartacaktır.

Kentin, kamu yararına tekrar ele geçirilmesine yönelik olarak tarihsel süreçte birçok pratiğin ortaya çıtığı görülmektedir. Bu süreç; 1960'larda durumcuların (sitüasyonistleri), insanların gündelik hayat ideolojisinden özgürleşmeleri adına, mimarlık ve kentçiliğin yapılı çevresini altüst edecek deneyimlerin arayışına geçmeleri ile başlar. Küresel ekonomik kriz sonrasında "tasarruf kentçiliği" (austerity urbanism) (Theodore ve Brenner, 2012) birçok Avrupa ülkesinde görülmeye başlanır (aktaran, Ferreri, 2015). Sonrasında geçici şehircilik pratikleri; gerilla (Guerilla), kendin-yap (DIY), pop-up, isyancı (insurgent), açık kaynak (open source), aşağıdan-yukarı (bottom-up) spontan (spontaneous), taktik şehirciliği (tactical urbanism) gibi çeşitli isimlerle ortaya çıkarii. Özellikle 2012 Venedik Bienali'nden itibaren temel konularında toplum için mimarlık ortamı arayışları görülür. Chippirfield kuratörlüğünde başlayan "ortak zemin" temasında Jüri özel ödülünü alan "spontan müdahaleler" başlıklı ABD pavyonunda, yeni, demokratik kentsel alanların gelişimine dayalı müdahaleleri içeren 124 projede; gerilla mimarlığından, pop-arta, katılımcı mimarlıktan kent işgali konularına kadar geniş ve farklı ölçeklerde konular ele alınır. Bu tarihten sonra, geçici şehircilik kavramı, mimarlık ve kentsel tasarım söylemlerinde önem kazanmaya başlar (Madanipour, 2017).

Stavrides (2018), Müşterek Mekân kitabında, Kentsel mekânın özgürleştirici potansiyeline işaret eder. Üretim ve tüketim dışında pek işlev görmeyen, giderek özelleştirilen ve dışlayıcı hale gelen kamusal alanların gündelik hayat düzeyinde kent hakkına davet ettiğini ifade eder. $\mathrm{Bu}$ sahne üzerindeki seyyar satıcılardan kaykaycilara, gerilla bahçecilerden protestoculara kadar çeşitli aktörlerin mekânın normalleştirilmesine meydan okuduklarını belirtir (Harrison, 2017).

Günümüz dünyasında değişen koşullara uyum sağlayabilen geçici kentsel mekânlar, mimarlar ve kent plancılarına yaratıcı tasarımlar konusunda ilham vermektedir. Bishop ve Williams (2012), "geçici faaliyetin, geleceğin daha belirsiz ve daha az güvenli olduğu bir dünyaya verdiği bir tepkiyi ve hızlı ekonomik, toplumsal ve teknolojik değişikliklere bir yanıtı temsil ettiğini belirtir (aktaran, Koyama, 2017). Düşük maliyetli ve düşük riskli stratejiler olarak geçici projeler, değişen koşullara ve taleplere hızlı bir şekilde yanıt verebilir. Bu ekonomik faydanın yanında toplumsal etkileşimi, eylemliliği içermesi bakımından sosyal yararları olduğu anlaşılmaktadır. Bunun yanında bazı örnekler üzerinden ekolojik, sürdürülebilirlik alanların da olumlu yönleri olduğunu söylemek gerekir. Bir yandan da sağladığı esneklik bakımından geçici şehircilik uygulamaları kentsel mekânda uygulanabilirliği ve barındırdığı potansiyeller açısından önemli bir olgudur.

Mimarlık ve şehircilik literatüründe yeni kamusal alanlar yaratma potansiyeli ile var olan geçici mekân paradigması, tüm kentsel dış mekânlarda üretilen geçici mekânlar, Lefebvre'in kent hakkı, Harvey'in işgal ile geri alma söyleminde, Certeau'nun stratejilere karş1 gündelik hayat içerisinde geliştirilen taktiklerinde bahsettiğinin hayat bulmuş hali olarak görülebilir. 1990'ların sonlarından bu yana, geçici kullanımlar kentsel kalkınmanın "katalizörleri" veya ekonomik düzelmenin ve yeni kentsel kültürlerin öncüleri olarak kavramsallaştırılmıştır (Lehtovuori ve diğerleri 2003; Haydn ve Temel 2006, Urban Pioneers 2007) (aktaran, Lehtovuori ve Ruoppila, 2012).

AB tarafından finanse edilen Berlin Teknik Üniversitesi'nde koordine edilen "Geçici kullanımlar için stratejilerAvrupa metropollerinde kentsel kalıntı alanlarının geliştirilmesi potansiyeli” konulu araştırma projesi, olan Urban Catalyst raporunda yerleştikleri alana göre farklılaşan geçici kullanım tipolojilerini belirlemiştir. Bunlardan biri parazit mekânlardır; buradaki geçici kullanım, mevcut kalıcı kullanımlara bağlı olarak geliştirilir ve mevcut potansiyellerden ve alanın kullanılabilirliğinden yararlanıriii. Parazit mekânlar; yaratıcı düşüncenin, sınırlılıklar içerisinde mevcuda dayanan-beslenen, eylemlilik potansiyelleri yaratabilecek mekânlar, üretmenin kısa süreli ve ekonomik yolu olarak görülmektedir. Bu doğrultuda çalışma, Augé'nin yok yerlerine, mekânsal müdahalenin katkılarıyla toplumsal eylemlilik katıldığında yeni bir tür kentsel mekân kazanımı olabilir mi? sorusunun cevabını arar. 


\section{Eylemlilik ve Görünürlük Bağlamında Parazit Müdahaleler}

Parazit misafir olduğu mekânın hayatta kalmasına katkı sağlamayan ancak hayatta kalabilmek için ev sahibinden beslenen, hayati tüm ihtiyaçlarını ondan karşılayan bir mekânsal müdahale olarak toplumsal eylemliliği ortaya çıkarmaktadır. (Myburg, J.,2014). Bu bağlamda parazit, misafir olduğu binaya zarar vermeden kendi işlevini yerine getiren ancak ev sahibi bina ile ilişkide 1srarc1, bulunduğu sürece ortamda geçici ve sömürücü bir tavır olarak da kendini ifade edebilir (Pit, M., Steller,K. \& Streng, G.,2017). Bu durumda paraziti çağdaş eklerden ayıran en belirleyici özelliği tutunduğu ev sahibi bina ile strüktürel, işlevsel ilişkiler kurarak enerjisinden ve atığından faydalanması ve eklemlendiği ev sahibi binanın eylemliliğine yeni bir anlam kazandırmasıdır. Parazitler; yeni potansiyel yaşam alanları yaratma, barınmaya ekonomik çözüm sunma, var olanı yeniden var etme, kullanılmayanı kullanılır hale işlevsiz olanı işler hale getirme, var olana değer katma bir yandan da provoke etme, zamandan tasarruf edici aynı zamanda pratik çözümler olarak pek çok imkân sağlamaktadır. Temelde kentsel müdahale biçimi olarak eklemlendiği konak binayı bir yandan görünür kılarken, içine aldığı yeni işlevi ile bir yandan da eylemliliğini devam ettirmektedir (Üstün Demirkaya, Maçka Kalfa, 2017). Bu bağlamda dünyadan seçilen örnekler, kentsel mekânın manipülasyonu ile eylem ve etkileşim ortamlarını yaratma potansiyelleri bağlamında, parazit müdahalelerin etkili bir araç olarak kullanıldığını göstermektedir (Resim 1).

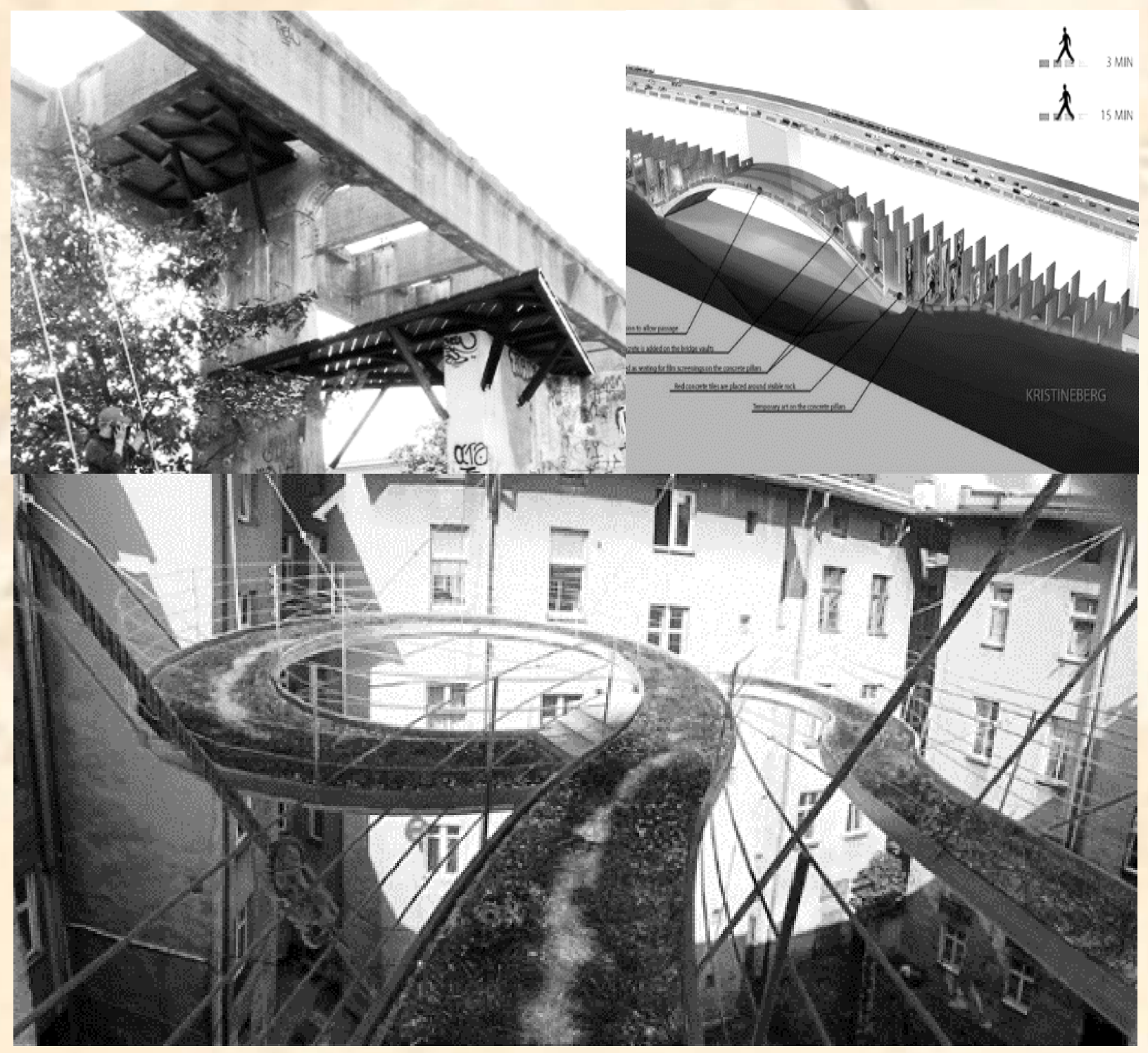




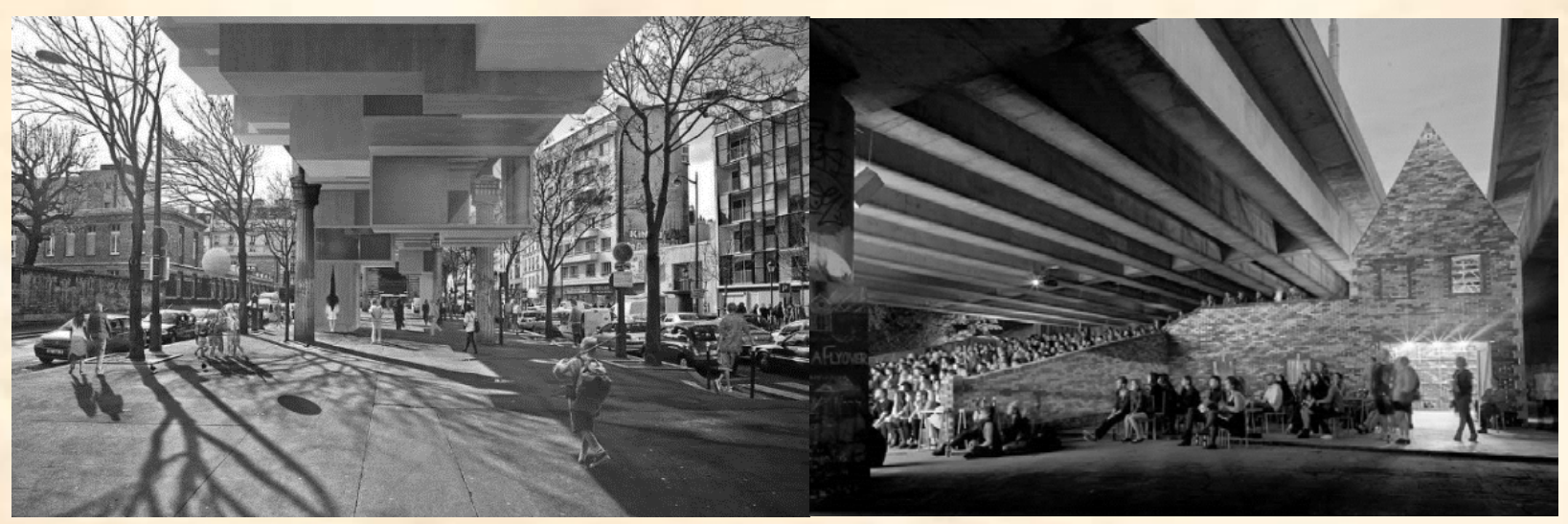

Resim 1. Dünyadan Kent ve Bina Ölçeğinde Parazit Strüktür Örnekleri

Sosyal etkileşime izin vermeyen, kalabalığın senkronize bir sürüklenme hareketini barındıran, hız eksenli ulaşım altyapıları, Auge'nin yok yerlerinin temel özelliği olarak ortaya çıkmaktadır. Burada birey; müşteri, yolcu ya da kullanıcıdır. Kollektif bir deneyime olanak tanımayan bu kalabalık yerlerin temel çelişkisi; sadece bireyin tanımlı eylemi ile ilgili olmasından ileri gelmektedir. Burada, olumsuz özellikleri ile Yok-yerleşen yerlerin yere dönüştürülmesinde köprü ve viyadüklere yapılan müdahaleleri içeren örneklere (Resim 1) yer verilmektedir. Bu örnekler vasıtasıyla, ulaşım altyapısı ve yok yer olma özelliklerini barındıran, çalışma kapsamında ele alınan Metrobüs müdahaleleri ile bağlamsal olarak ilişki kurulabilecektir. İlk görsel; 2007 yılında Aarhus'da Bureau Detours tarafından yerel yönetimle iş birliği içinde gerçekleştirdikleri, gençlerin grafiti çalışmalarını yapıp sergileyebilecekleri bir kent parkı yaratmayı hedefleyen bir çalışma. İkinci görsel; 2014'te Visiondivision tarafindan Stockholm'de Tranebergson Köprü strüktürüne eklemlenen yaya yolu önerisi ile alana bir dinamizm getirmesi öngörülmekte. Üçüncü görsel; Zalewski Mimarlık Grubu tarafından gerçekleştirilen mevcut yapılara asılan bir yeşil balkon uygulaması. Malka'nın Paris'te metro durağı hattı altına önerdiği sanat galerisi birimleri ile, Assemble tarafından Londra'da viyadük altına önerdiği geçici sinema projeleri, sosyal etkileşimi merkeze alan örnekler. Tanyeli'nin (1996) ifadesiyle yerle kurulan ilişkinin tanımlanmamış olması orayı yer yapar ve içinde bilinmezliği ve öngörülmezliği barındırır. Yukarıdaki örneklerde de yer olma çabasına yönelik olasılıklar ortamı yaratılmaya çalışıldığ gözlemlenmektedir. Hafızası olmayan yok-yerlerin bir örneği olarak görülen otobandan farklı olarak, bu çalışmanın ana mekânı olarak metrobüs, yolcu kimliğinin dışında bireyi yerle empatik bir ilişki kurması yönünde potansiyelleri barındırmaktadır.

\section{Stüdyo Deneyimi Üzerinden Yeni Kamusal Mekânların Tartışması}

Gündelik yaşam içinde mekânın kentliler tarafından nasıl kullanıldığının ya da kullanılamadığının analizini ve kentlilerin eylemlerini nasıl şekillendirdiği mekân algısını içerirken, kentsel bağlam var olan kentsel mekânların ya da boşlukların tasarım araştırmalarına girdi sağlamaktadır. Bu iki bağlamın ele alındığı bir mekân tasarımı yaklaşımı, tasarımın biçim üretiminin ötesine geçerek bir kamusallık nosyonu taşıdığı anlayışına temellenmektedir (Yorgancioğlu, Seyman Güray, 2018; Salama,1995; Salama \& Wilkinson, 2007; Salama, 2015). Bu çalışmada, Arendth'in kamusal alanın barındırdığını ifade ettiği eylemlilik ve görünürlük kavramları üzerinden, kamusal alana yapılan müdahalenin potansiyellerini tartışmak adına yer olarak; İstanbul'u doğu-batı doğrultusunda bağlayan ana ulaşım arteri olan E 5 karayolu üzerinde yer alan metrobüs durak ve üst geçitleri belirlenmiştir (Resim 2). İstanbul'un nüfus büyüklüğü ve her gün trafiğe çıkan araç sayısındaki artışa dayanarak yapılan İBB'nin 2011 Ulaşım Raporunaiv göre ortalama günlük kent içi ulaşım süresinin bir buçuk saat olduğu görülmektedir. Gündelik olarak trafikte geçirilen bu sürede toplu taşıma veya özel araç kullananların kentle genellikle karayolu çevresi üzerinden bir görsel teması bulunmaktadır. 


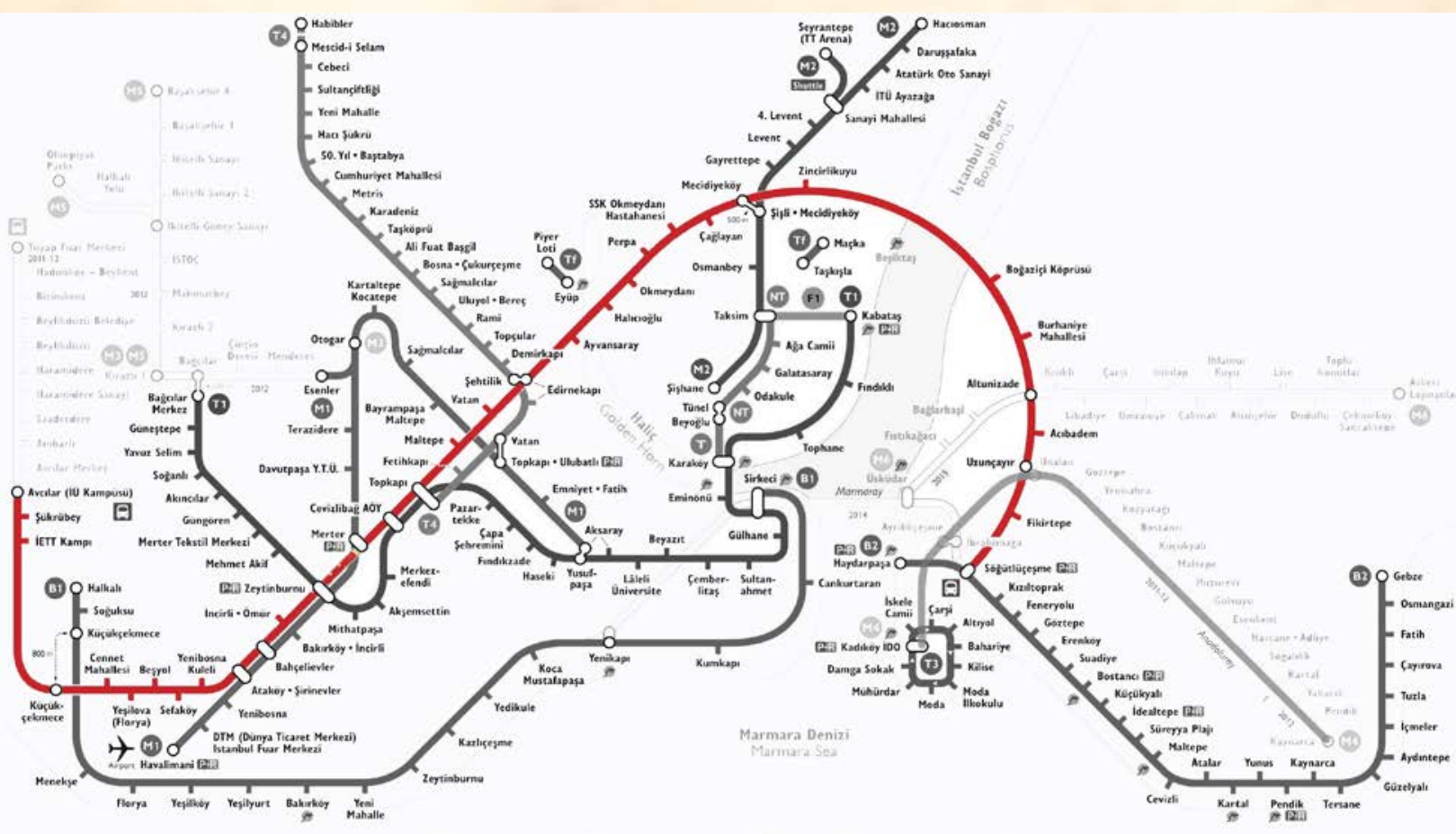

Resim 2. Metrobüs Durakları (Kaynak: https://rayhaber.com/2019/10/metrobus-duraklari-ve-haritasi/)

Metrobüs kentin ana arterlerinden kendisine ayrılmış yolda yoğun trafik engeli olmadan gidebilen araçlarla oluşturmuş bir toplu ulaşım sistemidir. Türkiye'de bir ilk olan Metrobüs sistemi İstanbul'da Topkapi-Avcılar hattında hizmete başlanmış, yapımına 2007 yılı başında başlanan 18,3 kilometrelik birinci etabı, sekiz ay gibi kısa sürede tamamlanarak 17 Eylül 2007'de açılmıştır. Metrobüsün ikinci etabı olan Zincirlikuyu ayağının tamamlanmasıyla durak sayısı 25'e yükselmiştir. Metrobüs hattının üçüncü etabı olan Söğütlüçeşme hattı İstanbul'un iki yakasını en kısa yoldan birbirine bağlanmıştır. Hattın son etabı olan Avcılar-Beylikdüzü güzergâhının ardından BeylikdüzüSöğütlüçeşme metrobüs hattı yolculuğu 83 dakikada sonlandırılmıştır. Metrobüs sisteminin E-5 karayolunda inşa edilmiş olması metrobüs sistemini E-5 karayoluna bağımlı bir değişken yapmakta, ev ve işlerine gidebilmek için kullandıkları metrobüs, yolcularını E-5 karayolunun ayrıcalıklı bir kullanıcısı haline getirmektedir. Kent iktidarının önemli bir öğesi olan E-5 karayolu kentlilerin hayatını zaman ve mekân arasında belirlemektedir (Üngür, 2018). Metrobüs-kentli ilişkisini anlamada David Harvey'in zaman-mekân sıkışması kavramından yola çıkarak kapitalist formülasyonların oluşumuna coğrafi etkenler üzerinden bakmak gerekliliği ortaya çıkmakta, bu da mekânın öznel içeriklerini ve olgularının önemini hatırlatmaktadır (Katznelson, 2003). Harvey'in zaman mekân sıkışmasında zaman ve mekân değer kaybetmemekle beraber mekân, zaman karşısında öznel yapısını kaybetmektedir. Nitekim metrobüs, kendisinin varolma sürecinde çevresini de oluşturup dönüştürmüş, bir anlamda İstanbul'a özgü bir mekânsallık kazanmıştır. Bugün mimarlık olarak tanımlanmayan ve "formsuz" olduğu iddia edilen metrobüse bir anlamda form kazandırmak ve görünürlüğünü artırmak kentsel mikro müdahaleler gerektirmektedir. Metrobüs mimarisine özgü ilk müdahale gerektiren birimler, cadde kotundan ayrıldığımız ilk basamakla birlikte karşımıza çıkan merdivenler, rampalar, asansörler, üst geçitler, güvenlik kulübeleri, bekleme platformları, saçaklar, oturma elemanları, bilgi ve reklam panoları, aydınlatma elemanları, bir araç ve mekân olarak metrobüsün kendisidir. Tüm bu bileşenler sayesinde metrobüs, şehrin pek çok farklı bölgesinden geçmesine rağmen hemen hemen her durakta aynı yapıyı sergilemektedir. Durakların kendilerine özgü biçimleri, tekillikleri yok sayılmaktadır. "Yer-olmayan" tartışmasını hatırlatan bu yaklaşım, ilişkilenebilir olma halinin yapıların görünürlüğüne bağlı olduğu gerçeğini hatırlatır. İstanbul'da E-5 ortasında bulunmalarına ve gündelik hayatın içinde sıkça kentli ile karşılaşmalarına rağmen metrobüs duraklarının "görünürlüğ̈̈̈" yok denecek kadar aza indirgenmiştir.

Yok-yer olarak E-5 sadece belirli güzergâhlar arasında ulaşım amaçlı kamusal alanlar olmasına karşın, görsel anlamda oldukça özelleşmiş bir yapıdadır. Reklam panoları ve bilboardlar ile binalar, üst geçitler ve duvarlar çeşitli mesaj ve tüketim araçları olarak kullanılmaktadır. Statik ve tanımlı bir eylem ve vitrine dönüşen bu kamusal alanların nasıl özgürleşme alanlarına dönüşebileceği, gündelik ritmi bozacak yeni eylemselliklere imkân verecek müdahalelerin tartışmaları bağlamında, mimari tasarım 4 stüdyosunda bu alanlara eklemlenme problem olarak ortaya konulmuştur. Tasarım başlığı olarak Metrobüs durağında tasarlanacak parazit bir bilgilendirme kutusu (info-box) istenmiştir. Parazit 
kurgu; mevcut yapıya eklemlenecek, yaya sirkülasyonunu engellemeyecek ve belirli bir eylemi ve/veya temayı içerebilir olacaktır (Resim 4).

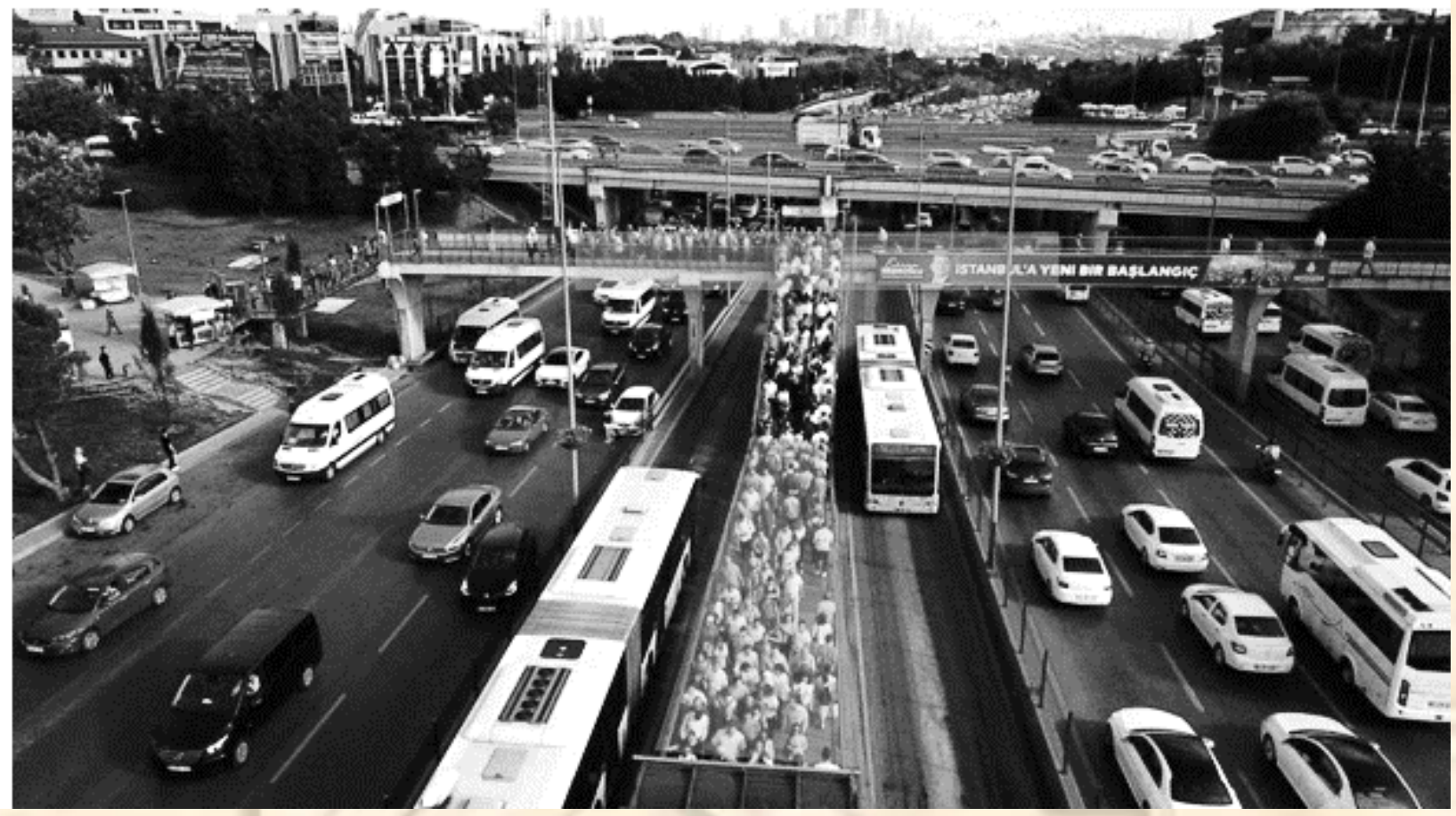

Resim 3. Metrobüs ile parazit strüktür ilişkisinin kurulabileceği alanlar

Metrobüs tasarım stüdyosu öğrencilerinin eklemlenme problemine karşı geliştirdikleri tavır; eylemlilik ve görünürlük üzerinden olmuştur. Karşılaşılan en büyük problem; yerin yaya trafiğinin yoğunluğu ve yürüme alanının metrobüs durak ve üst geçitlerin darlığı olmuştur. Diğer taraftan, yoğun yayanın bulunduğu bu ortam; bazı öğrencileri projelerinde toplumsal veya gündelik hayatta unutulan temaları görünür kılmak adına belirli temalar üzerinden fikir geliştirmeye yönlendirmiştir. Kamusal alanların özelleşmesi bağlamında konuya eleştirel yaklaşan bazı projelerde kendi mesajını verme içgüdüsü görünürlük bağlamında değerlendirilmiştir. Bu yaklaşımdaki projelerde, E-5 Karayolunu kullanan yaya ve taşıt sürücülerine yönelik ticarileşen vitrin mekân, temaların sergilendiği bir enstalasyon sahnesine dönüștürülmeye çalıșılmıștır. Bu sayede var olan algısal duruma kendi dinamikleri içinden taktikler geliştirilmiş̧ir. Kadın cinayetleri, trafik kazaları, kentin resmi olmayan hafızaları, insan hakları, kentsel atığın değerlendirilmesi gibi belirli temalar belirleyen öğrenciler çalışmalarında konuya ilişkin kolajlar yaparak, bu temaları içeren bilgilendirme alanları tasarlamışlardır.

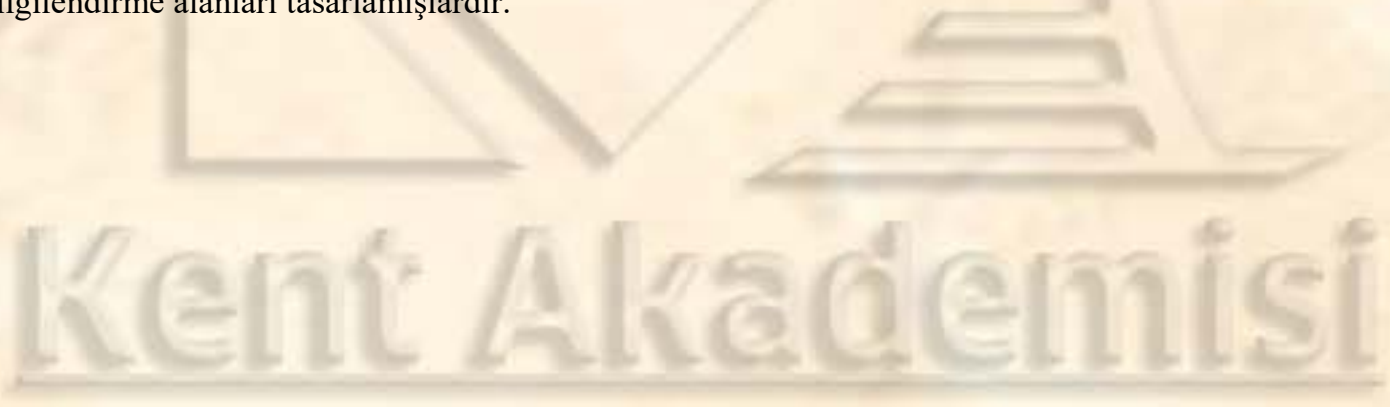




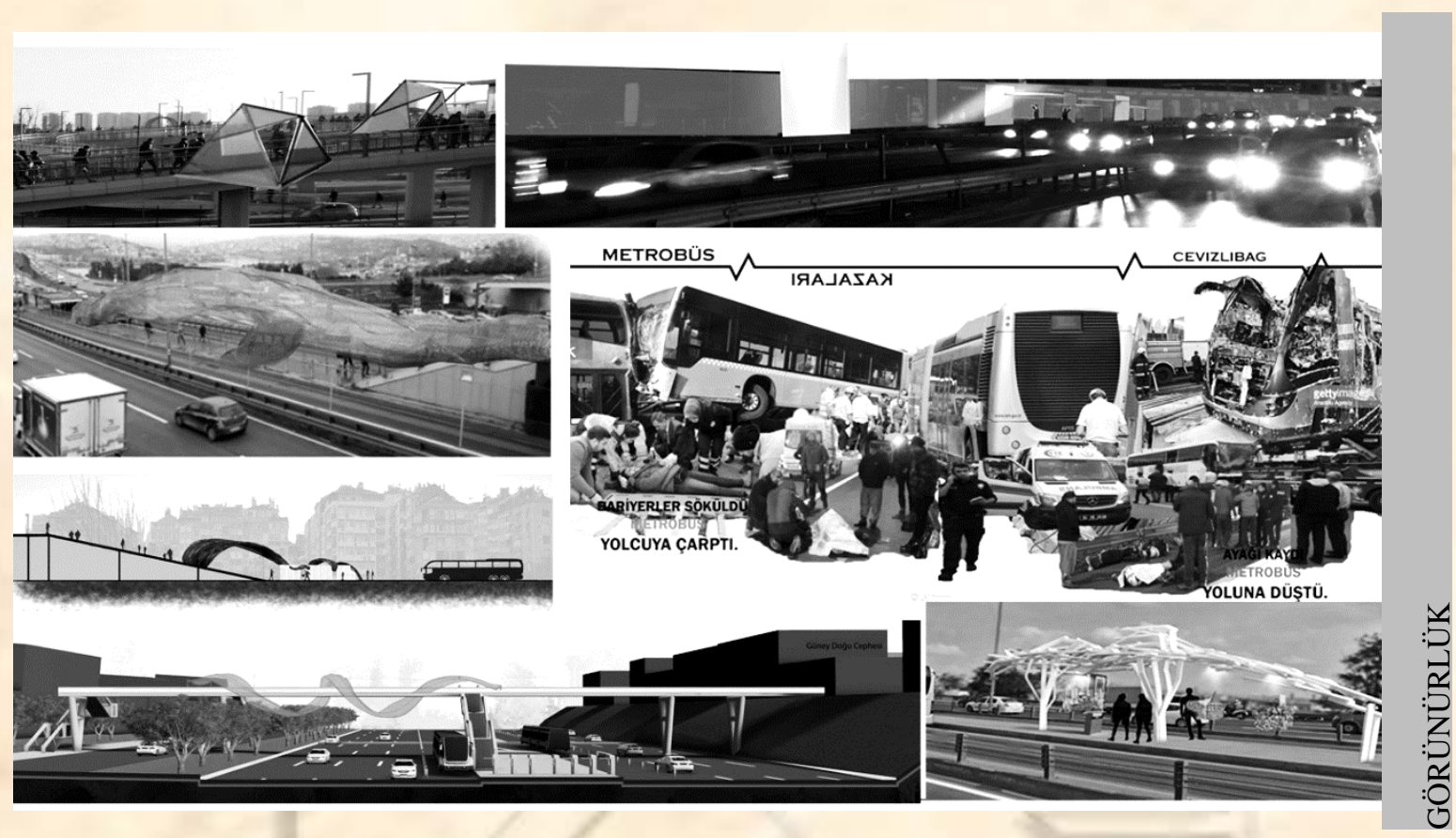

Resim 4. Tasarım Öğrencilerinin Görünürlük Bağlamında Parazit Strüktürel Yaklaşım Örnekleri

Görünürlük bağlamında öğrencilerin tasarladığı strüktür örneklerinden bir tanesi toplumsal hafizanın mekanlarını vurgular. Toplumsal amneziyi eleştiren kolaj çalışmasıyla başlayan süreçte öğrenci; harita ve turist rehberlerinde yer verilenin dışında, kentin yazılı olmayan hafızanın izlerini sürer ve bunun için seçtiği Ayvansaray metrobüs durağına hologram ekranların yerleştirildiği bir strüktür tasarlar. Metrobüs bekleme sürecinde yolcu-birey, bir sergi alanı vazifesi gören bu örtü ile bir hafıza yolculuğu yapar ve yolcu kimliğinin dışında, ona tanımlanmamıș bir eylemde yer alır. Bir diğer örnekte; metrobüs kazalarının analizini yapan öğrenci, Cevizlibağ durağında yerden belirli bir yüksekliğe çıkan kapalı bir simülasyon alanını içeren bir tasarım önerisinde bulunmuştur. Tasarım önerisi; strüktürü ve kapalı mekânın sağladığı cephe ile otoyoldaki sürücü-bireye görsel mesajını verirken, yarı açık mekânın içinde simüle edilen kazalar ile yolcu-bireye bir deneyim alanı yaratmaktadır.

Öğrencilerin problemi ele alışlarındaki bir diğer yaklaşım eylemlilik bağlamında olmuştur. Metrobüsün E-5 üzerinde devam eden biçimsel tekrarına tavır olarak gösterilen eylemsel tekrarlılık, müdahale olarak metrobüsün devamını içerir. Ancak parazitin biçimi eylemsel tekrarın karşısında daha cesurdur. Kentlinin özgürleşme isteğine cevap arayan tasarımlar kimi zaman malzemesi, kimi zaman rengi ve biçimi ile tamamen metrobüsten ayrılır. Kentli her durakta zaman ve mekân sıkışmasından artık uzaklaşarak kenti monotonluktan uzakta yaşamaya başlayacaktır. Eylemlilik bağlamında öğrencilerin tasarladığı strüktür örneklerinden bir tanesinde biçim olarak her ne kadar metrobüsün kendisi gibi davranmaya çalışsa da malzeme olarak tamamen farklılaşan bir mekân tanımlanır. Bu mekân gün içinde insan sayısı ve etkinliklerinin çeşitliliği ile devamlı bir devinim halinde karşımıza çıkar. Metrobüs durağında yapılan yürümek, koşmak, durmak ya da seyretmek gibi gündelik eylemlerin aynası olan strüktür kullanıcısına da şeffaf ve kentle iççice bir mekân vadeder. Eylemlilik örneklerin tümünde asal hedef metrobüsteki gündelik yaşam eylemlerinin olabildiğince mekânsal isteklerinin karşılanması olmakla beraber, bu eylemlerin her metrobüs durağını tarif edebilecek nitelikte kimlik kazanan malzeme ve tasarımlarıyla beraber düşünülmesidir. 


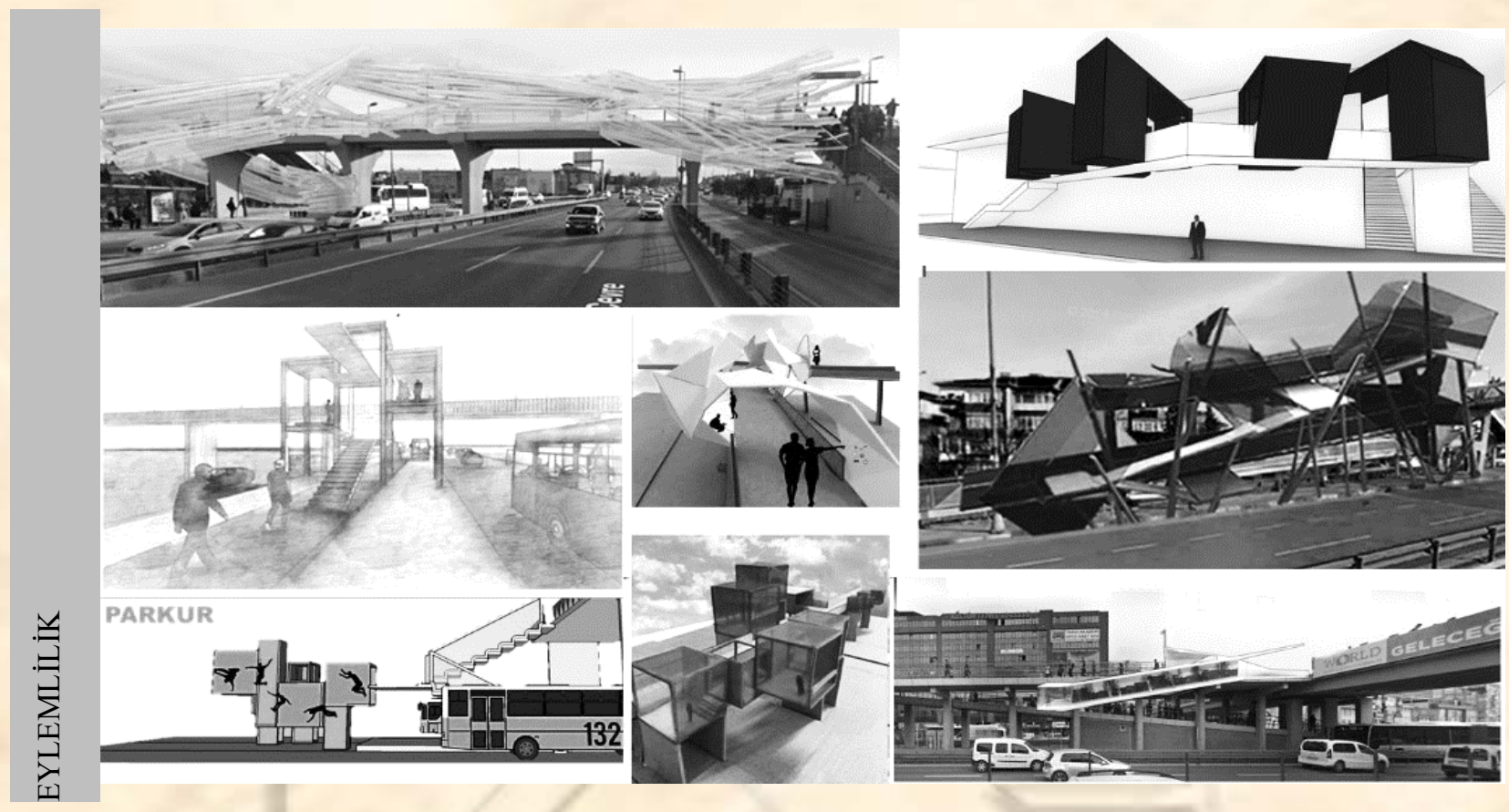

Resim 5. Tasarım Öğrencilerinin Eylemlilik Bağlamında Parazit Strüktürel Yaklaşım Örnekleri

\section{SONUÇ:}

Bu çalışma, kamusal alanda pasif ve tüketim odaklı seyirci pozisyonuna düşürülen insanın, özgürleşmesine olanak sağlayacak mekânsal müdahalelerin neler olabileceği sorgulanmıştır. Bu çerçevede, kamusal alan ve kentlilik ilişkisi tartışmalarına yer verilmiştir. Kent hakkının geri alınmasında, kamusal alanda insanı özgürleştirici müdahalelerinin önemli olduğu anlaşılmıştır. Gelişen teknoloji ve küreselleşmenin etkileri ile yer özelliği olmayan yerlerin yeni kamusallıkların üretimine olanak sağlayabileceği görülmüştür.

Çalışmanın sonucunda, Arendth'in kamusal alanı ele alırken ortaya koyduğu eylemlilik ve görünürlük temel kavramları üzerinden, kamusal alana yapılan parazit müdahalenin yapılı çevreye ilişkin başka türlü mimari üretim pratiklerinin mümkün olabileceğini göstermiştir. Parazit mimari tasarım üretimini alternatif bir mekân tasarımı yaklaşımı olarak mimari tasarım stüdyosundaki öğrenme sürecine katkıları, öğrencilere özgür mekân kavramını ve beraberinde yeni kamusal müdahale biçimi olarak parazit mekânın mekân-kent-kentli arasında alternatif ilişkisini deneyimletmiştir. Diğer yandan kentlilik bilincinin nasıl kamusallıklar gerektirdiği ve kamusal alanın kentli tarafından yaratıcı taktiklerle nasıl ele geçirilebileceği hakkında fikir sahibi olunmuştur.

\section{KAYNAKÇA:}

Arendth, H. (1994). İnsanlık Durumu. (Çev. Bahadır Sina Şener), İletişim, İstanbul.

Augé, M. (2017). Yok-Yerler. (Çev. Turhan Ilgaz), Daimon Yayınları, İstanbul.

d'Entreves, M. P. (2019). Hannah Arendt, içinde, The Stanford Encyclopedia of Philosophy. (Der. Edward N. Zalta) (Elektronik Kaynak). Erişim Tarihi: 4.9.2019. https://plato.stanford.edu/entries/arendt/\#CitPubSph .

Ferreri, M. (2015). The seductions of temporary urbanism, içinde, Ephemera Journal, (Elektronik Kaynak). Erişim Tarihi: 5.9.2019. http://www.ephemerajournal.org/sites/default/files/pdfs/contribution/15-1ferreri.pdf

Harrison, M. (2017). Stavros Stavrıdes' new book common space: the city as commons, içinde, Agent of Alternatives, (Elektronik Kaynak). Erişim Tarihi: 4.9.2019. http://agentsofalternatives.com/?p=2530 
Harvey, D. (2019). Postmodernliğin Durumu. (Çev. Sungur Savran), Metis, İstanbul.

Katznelson, I. (2003). Önsöz (çev. Mehmet Moralı), içinde, Sosyal Adalet ve Şehir (David Harvey), Metis Yayınları, İstanbul.

Koyama, M. (2017). Can Temporary Urbanism be a Permanent Solution? Urban Spaces in Liquid Times, içinde, Medium, (Elektronik Kaynak). Erişim Tarihi: 5.9.2019.https://medium.com/@megukoyama/can-temporaryurbanism-be-a-permanent-solution-urban-spaces-in-liquid-times-643d423ae4fc

Lefebvre, H. (2015). Şehir Hakkı. (Çev. Işık Ergüden), Sel Yayın, İstanbul.

Lehtovuori, P., Ruoppila, S. (2012). Temporary Uses As Means Of Experimental Urban Planning, içinde, Serbian Architectural Journal, s. 4, (Der. John Henneberry), (Elektronik Kaynak). Erişim Tarihi: 5.9.2019. https://www.researchgate.net/publication/275259733_Temporary_uses_as_means_of_experimental_urban_planning

Madanipour, A. (2017). Cities in Time Temporary Urbanism and the Future of the City, s.3-4, Bloomsbury Academic Press, London.

Myburg, J. (2014). MESOPARASITE. A Symbiotic Affair. Unitec Institute of Technology.

Pit, M., Steller, K. \& Streng, G.(2017). T02 essay parasitic architecture.pdf. (Elektronik Kaynak). Erişim Tarihi: 5.9.2019. http://www.gerjanstreng.eu/files/T02\%20essay\%20parasitic\%20architecture.pdf.

Ranciére, J. (2010). Özgürleşen Seyirci. (Çev. Burak Şaman). Metis, Istanbul.

Salama, A. M. (1995). New Trends in Architectural Education: Designing the Design Studio. Tailored Text and Unlimited Potential Publishing, USA.

Salama, A. M. (2015). Spatial Design Education: New Directions for Pedagogy in Architecture and Beyond. Ashgate Publishing, UK, USA.

Salama, A. S., Nicholas Wilkinson, N. (editörler.) (2007). Design Studio Pedagogy: Horizons For The Future, The Urban International Press, UK.

Stavrides, S. (2018). Müşterek Mekân. (Çev. Cenk Saraçoğlu). Sel Yayıncılık, İstanbul.

Üngür, E. (2018). Kentleşmeyi Gerçekleştiren Biyopolitik Bir Araç Olarak D-100 Karayolu, içinde, Mimarist, s.63, s. 32-36, İstanbul Mimarlar Odasi.

Üstün Demirkaya, F., Maçka Kalfa, S. (2017). Biyolojik Yaşam Şeklinden Mimari Ürüne: Konak Binada Parazitik Mimari, içinde, Fen, Matematik, Mühendislik ve Doğa Bilimleri Araştırmaları, s. 242-250.

Yorgancıoğlu, D., Seyman Güray, T. (2018). Mimari Tasarım Eğitiminde Alternatif Yaklaşımlar: Bir Mekân Tasarımı Stratejisi Olarak "Parazit Mimari", içinde, MEGARON 2018;13(1):144-155, DOI: 10.5505/megaron.2017.74946

i Sitüasyon (durum) yaratmak; geçici bir mikro-dünya ve bir olaylar oyunu yaratmak olarak görülmektedir (aktaran, Ojalvoi). ii Dünyadaki örnekleri üzerinden yapılmış döküman incelenebilir; Bottom-Up Urbanism: A Survey of Temporary Use in Europe, https://issuu.com/david.t.glick/docs/bottom-up urbanism dglick, 5.9.2019.

iii http://www.templace.com/think-pool/attach/download/1_UC_finalR_synthesis007b.pdf, 5.9.2019.

iv http://ibb.gov.tr/tr-TR/kurumsal/Birimler/ulasimPlanlama/Documents/\%C4\%B0UAP_Ana_Raporu.pdf 4.9.2019. 